\title{
Abnormal embryos of sharpnose sharks, Rhizoprionodon porosus and Rhizoprionodon lalandii (Elasmobranchii: Carcharhinidae), from Brazilian coast, western South Atlantic
}

\author{
CAMILA MAYUMI HIRATA DOS SANTOS ${ }^{1,2}$ AND OTTO BISMARCK FAZZANO GADIG ${ }^{2}$ \\ ${ }^{1}$ UNESP, Campus de Rio Claro, Rua 24A n ${ }^{\circ}$ 1515, 13506-90o, Rio Claro, São Paulo, Brazil, ${ }^{2}$ Laboratório de Pesquisa de \\ Elasmobrânquios, UNESP, Campus Experimental do Litoral Paulista, Praça Infante Dom Henrique s/n, 11330-90o, São Vicente, \\ São Paulo, Brazil
}

\begin{abstract}
This study presents the second worldwide report on abnormal embryos of the sharpnose sharks, Rhizoprionodon, based on the two species (Rhizoprionodon porosus and Rhizoprionodon lalandii) occurring on the Brazilian coast. For R. porosus two conjoined twin embryos showing complete duplication of the vertebral column, viscera and several external structures (head, first and second dorsal fins, pectoral fins), and scoliosis in both axis at the pelvic fin level are reported. The three embryos of $\mathrm{R}$. lalandii exhibited numerous lordosis and kyphosis along the entire vertebral column. The possible relationship between anomalies and the human major threats to sharks is discussed based on previous reproductive, genetic and ecotoxicological studies on R. lalandii for southern Brazil.
\end{abstract}

Keywords: anomaly, anatomy, morphology, elasmobranch, conservation

Submitted 11 February 2014; accepted 28 April 2014

\section{INTRDDUCTIDN}

Study cases of abnormalities in elasmobranchs are mostly focused on partial or complete albinism and leucism (e.g. Joseph, 1961; Nakaya, 1973; Teixeira \& Araújo, 2002; Ben Souissi et al., 2007; Ball et al., 2013) and on morphological body deformities related, for instance, to incomplete fin-head fusion in batoids (skates and rays) and skeletal abnormalities of the vertebral column, recorded since 1642 (Driggers et al., 2012). Most published information on prenatal abnormalities of elasmobranchs were produced during the last 30 years and, there are a few studies if compared to land vertebrates, probably due to the relative unavailability of specimens of sharks and rays until recent times, the nature of these abnormalities, resulting in prenatal death, and, in a general view, the remarkable increase of interest to investigate other biological and anatomical parameters.

Several elasmobranch taxa were reported exhibiting some skeletal anomaly during embryonic development (Ford, 1930; Gopalan, 1971; Goto et al., 1981; Heupel et al., 1999; El Kamel et al., 2009; Delpiani et al., 2011; Galván-Magaña et al., 2011; Hevia-Hormanzábal et al., 2011; Mejia-Falla et al., 2011; Driggers et al., 2012; Guida et al., 2013; Muñoz-Osorio et al., 2013; Wagner et al., 2013). Brazilian studies on elasmobranch prenatal body abnormalities are restricted to some case reports based on few specimens (Gomes et al., 1991; Rosa et al., 1996; Teixeira \& Araújo, 2002; Mancini et al., 2006; Bornatowski \& Abilhoa, 2008). The most comprehensive Brazilian data available were provided by Ribeiro-Prado et al. (2008) describing different anomalies in six batoid species from southern Brazil.

The sharpnose shark genus Rhizoprionodon Whitley, 1929, is one of the most abundant small coastal predatory sharks in the tropical to temperate areas around the world, having at least seven known species (Ebert et al., 2013). On the Brazilian coast, the two recorded species, Rhizoprionodon porosus (Poey, 1861) and Rhizoprionodon lalandii (Müller \& Henle, 1839) are an important elasmobranch resource caught by the small to medium scale fisheries along the coastline (Motta et al., 2005). Despite several studies concerning the biology and population parameters of these species in Brazil (e.g. Ferreira, 1988; Lessa, 1988; Motta et al., 2005, 2007; Andrade et al., 2008), no previous published data reports any chromatic or morphological abnormality and, even in global scale, there is only one published paper describing anomaly in a sharpnose shark Rhizoprionodon acutus (Rüppell, 1837) from India (Gopalan, 1971). Thus, the present paper reports the second worldwide record of abnormalities in this genus, based on two abnormal conjoined embryos of Caribbean sharpnose shark, $R$. porosus and vertebral deformities in three embryos of the Brazilian sharpnose shark, $R$. lalandii, both commercially and ecologically important small shark species of the Brazilian coast, western South Atlantic, with a discussion on the possible relationship of the major human threats to these anomalies. 


\section{MATERIALS AND METHODS}

The two conjoined embryos of Rhizoprionodon porosus were removed from a pregnant female caught by artisanal fisheries using monofilament gillnets at Ilhéus, south Bahia State, north-east Brazil $\left(\sim 14^{\circ} 45^{\prime} \mathrm{S}-38^{\circ} 59^{\prime} \mathrm{W}\right)$ in May 2000. The three R. lalandii were from two pregnant females, caught by the small coastal gillnets in Praia Grande, São Paulo State, south-east Brazil $\left(\sim 24^{\circ} 01^{\prime} S-46^{\circ} 26^{\prime} \mathrm{W}\right)$, one from a female in 2007 and two from another in 2009. For both species, only the abnormal embryos were donated by the fishermen to researchers. After the species identification, according to Figueiredo (1977), the specimens' total length (TL in mm) was measured, preservation was in $10 \%$ formalin and $70 \%$ alcohol, they were submitted to digital photographs, examined under light stereomicroscope $(200 \times)$, radiographed in ventral and lateral views, eviscerated to gross visualization of the pericardial and abdominal organs (R. porosus), and deposited at the UNESP Elasmobranch Collection ( $R$. porosus-UNESP/ CLP 0025; $R$. lalandii-UNESP/CLP 0026.1, 0026.2 and 0026.3).

\section{RESULTS}

The conjoined Rhizoprionodon porosus were mid-term female embryos (Figure $1 \mathrm{~A}$ ), measuring $182 \mathrm{~mm} \mathrm{TL}$, and presented general aspect agreeing to an embryo of this species at this developmental stage, with dermal denticles completely formed along the entire body surface. External morphology showed the bifurcation occurring at the pectoral fin origins, resulting in two complete heads (both had well developed eyes, a nasal aperture pair, similar distributional patterns of the ampulary system pores and five pairs of gill slits), two pectoral fin pairs, two first and second dorsal fins, all structures similarly developed in both embryos, except the upper caudal fin lobe, which the left one was less developed than the right. Ventrally, the duplication reached the cloacal region, with one genital aperture, one female pelvic fin pair, one anal fin (distinguished from the second dorsal by its proportional dimensions and presence of the Rhizoprionodon diagnostic pre-anal dermal ridges) and one lower caudal lobe.

The skeletal structures associated with cephalic region, pectoral and dorsal fins duplications (chondrocranium, gill arches, pectoral girdles, first and second dorsal fins skeleton) were formed and also duplicated. The vertebral column was entirely duplicated (Figure 1), reaching the tip of the caudal fin. The number of precaudal vertebrae was the same for both axes $(=69)$. At the pelvic girdle and cloacal area, both presented scoliosis (Figure 1). In the right axis the curvature was located slightly anterior to those in the left axis, it was ' $U$ ' shaped and involved at least eight vertebrae. In the left axis the scoliosis was ' $\mathrm{V}$ ' shaped, with up to six vertebrae (respectively below and above in the Figure 1). The vertebral centra, except at the curvature zone, presented normal aspect, with concave ends and separated by the symmetrical intervertebral discs.

A visceral gross analysis showed duplication in all main organs. Each pericardial cavity had one heart, more developed in the left embryo. Abdominal cavity with bilobed livers and complete digestive tracts, but, unlike the pericardial cavity, it was more developed in the right embryo. Concerning the reproductive apparatus, both were females. The right embryo had the left oviduct less developed and the left embryo had the right oviduct smaller, resulting in a pattern where the two smaller oviducts were positioned along the join line between the two abdominal cavities.

The three Rhizoprionodon lalandii were near-term male embryos, between 273 and $276 \mathrm{~mm}$ TL (Figure 2), all presenting kyphosis and lordosis. Despite the column deformities, which affected the general body aspect, no additional external abnormality was detected in the head and fins morphology. One specimen (Figure 2A) developed a kyphosis at the pectoral fin level, and a less accentuated lordosis above the vertebral abdominal area below to the first dorsal fin. Vertebral axis at the caudal peduncle suffered one-turn column twist, rolling down to the right side, with helicoidal aspect. The total precaudal vertebrae number was 83 . The specimen B in the same figure had a small lordosis, followed by a kyphosis at the level of the pectoral fins which continued to form a deep lordosis below the first dorsal fin, resulting in an external deep concavity on the shark back. Posterior to that region there was a sequence of slight kyphosis and lordosis and a half-twist at pre-caudal point. In the specimen $\mathrm{C}$, from the same pregnant female of $B$, the general pattern was similar to its relative, but had less angular curvatures at the axis, and the post-pelvic area exhibited a long curvature initiated at the second dorsal fin level, forcing down its caudal fin. For all $R$. lalandii specimens, the external dorsal surface reflected those deformities by humpbacks (kyphosis) and depressions (lordosis). The number of precaudal vertebrae was 86 in both $B$ and $C$ specimens.

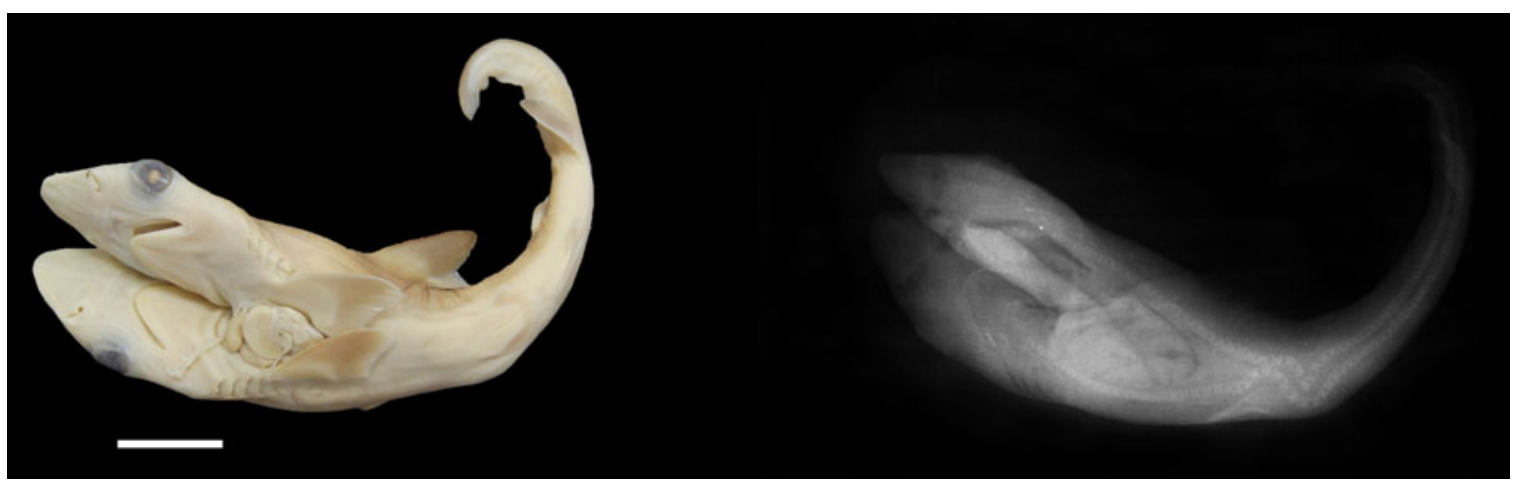

Fig. 1. External morphology and radiography of the Rhizoprionodon porosus conjoined twin embryos from Ilhéus, Bahia, north-east Brazil; white scale bar $=$ $2 \mathrm{~cm}$. 


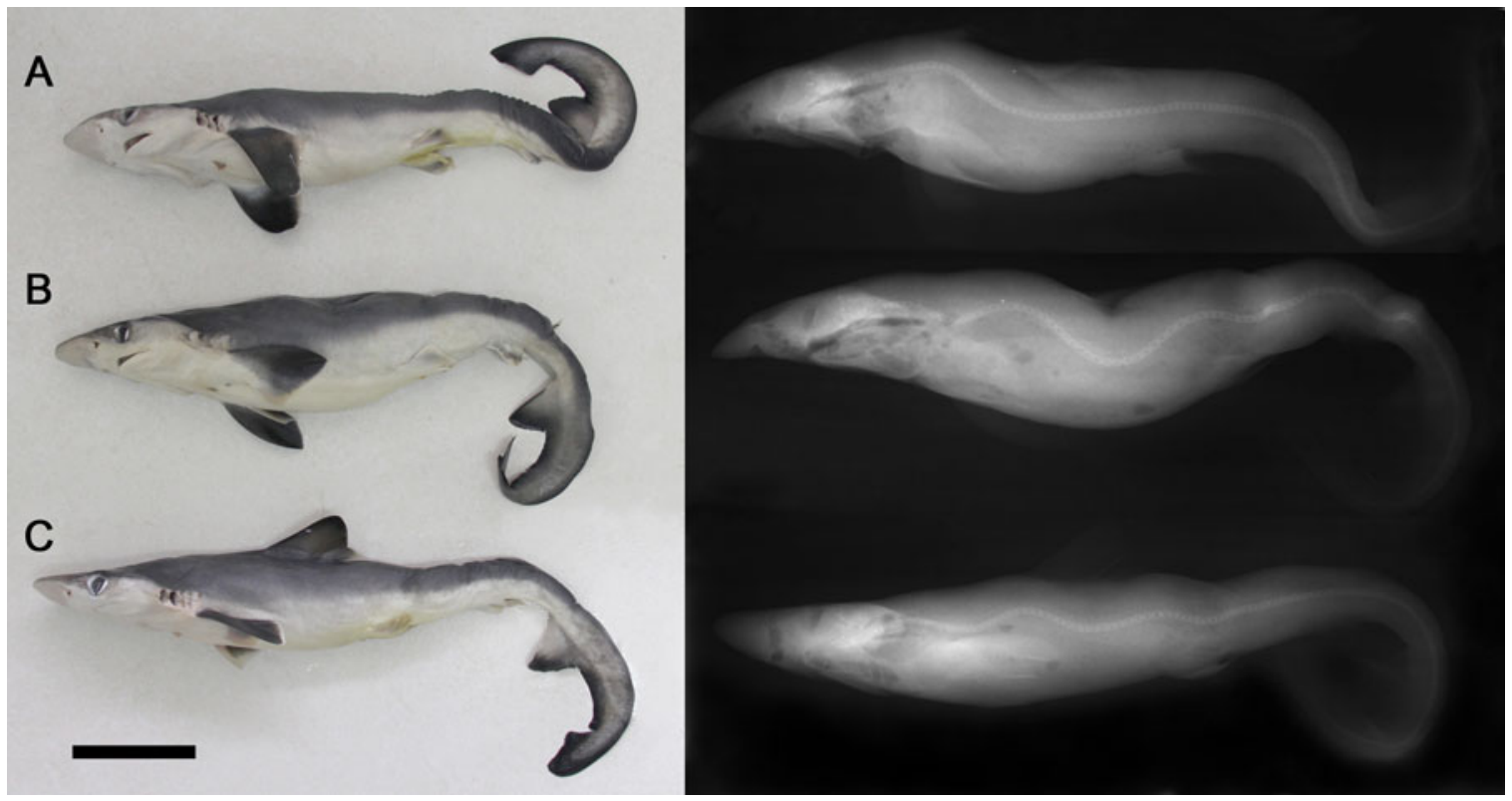

Fig. 2. External morphology and radiography of the three abnormal embryos of Rhizoprionodon lalandii from São Paulo coast, south-east Brazil; black scale bar $=$ $5 \mathrm{~cm}$.

\section{DISCUSSION}

Most data on conjoined elasmobranch embryos describe dicephalic twins, and not all descriptive studies focused on the exact degree of axial bifurcation (Ford, 1930; Goto et al., 1981; Bejarano-Álvarez et al., 2011; Delpiani et al., 2011; Wagner et al., 2013). The general aspect of the abnormal Rhizoprionodon porosus embryos here studied resembles the dicephalic Galeorhinus galeus (Linnaeus, 1758) analysed by Delpiani et al. (2011), having two completely separated heads, duplication of the vertebral column and both dorsal and caudal fins, a single pelvic fin pair, anal fin, and ventral caudal lobe, but differs mainly by the two pairs of pectoral fins and a more posterior fusion of the trunk of $R$. porosus. Unfortunately these authors did not provide a pericardial and abdominal description for comparative purposes.

Despite the abnormalities, the embryos of two Brazilian Rhizoprionodon species show general external morphology accordingly with the embryonic developmental stages found for those species for the same geographical areas where the pregnant females were captured. Size at birth of $R$. porosus from north-east Brazil was estimated about $330-370 \mathrm{~mm}$ TL (Mattos et al., 2001), corroborating the mid-term developmental stage for the specimen here studied (182 mm TL). Likewise, the specimens of $R$. lalandii here studied are regarded as near term, since, the newborns from southern Brazil have about 300-320 mm TL (Motta et al., 2007).

The vertebral counts also fit with previous observations for both species (Springer, 1964). In several cases, the vertebral number verified in abnormal individuals is according to that found in healthy ones of the same species (Heupel et al., 1999; Delpiani et al., 2011), as herein noted for Rhizoprionodon. However, some alterations of the external morphology of embryos recorded in some species reflect differences in the skeleton, as observed by Wagner et al. (2013) in a dicephalic Carcharhinus leucas (Müller \& Henle, 1839) having two very enlarged heads and a less developed posterior trunk. These authors found vertebral counts of $88-89$ versus the reported range of 208-227 in normal specimens (Garrick, 1982). Delpiani et al. (2011) also reported smaller vertebral counts in anomalous Galeorhinus galeus.

The conjoined twins of Rhizoprionodon porosus are parapagus dicephalus, a type of anomaly reported for several vertebrate taxa, from fish to mammals (Kamiya et al., 1981; Spencer, 2000; Kaufman, 2004; Kompaje, 2005; Galván-Magaña et al., 2011; Petrescu-Mag et al., 2011). In such deformity, the embryos have two heads with separate braincases, they are attached laterally, with the posterior region fused in different degrees, and present the same gender (Spencer, 2000), as observed in the embryos of this study, both females. This malformation occurs in early embryonic development, but there is much controversy whether it is the result of fusion of two embryonic discs (Spencer, 2000) or fission of a single disc (Kaufman, 2004). Although the genetic and chemical bases of this alteration are not yet known, hypotheses about exposure to substances and genetic factors have been raised (Kaufman, 2004; Petrescu-Mag, 2011).

The post-natal survival rate in anomalous embryos is expected to be very low for deformities involving the axis bifurcation, and the only reported exception, to date, refers to one free swimming dicephalic cownose ray, Rhinoptera steindachneri Evermann \& Jenkins, 1891, caught alive in the Gulf of Mexico (Castro-Aguirre \& Torres-Villegas, 1979). In reference to anomalies on the vertebral column of nonbifurcated embryos, as herein studied for Rhizoprionodon lalandii, survival of newborns has been recorded for some species in the wild (Ford, 1930; Hoenig \& Walsh, 1983; Heupel et al., 1999) and for an impressive number $(\sim 35 \%)$ of captive grey nurse shark, Carcharias taurus (Rafinesque, 1810) (Anderson et al., 2012; Tate et al., 2013). In these cases, the pre-pelvic curvatures of the axis (kyphosis/lordosis/scoliosis), although severe, seem to be less harmful for swimming purposes than helicoidal twists of the axis at postpelvic area in the caudal peduncle. The caudal twist found in $R$. lalandii, a small coastal species, would prevent the animal from surviving long after birth, due to its compromised 
swimming capabilities for gill ventilation and movements for hunting, avoiding predators, searching for sexual partners, as the same verified for embryos of other sharks (Pastore \& Prato, 1989; Mancini et al., 2006; Muñoz-Osorio et al., 2013). Thus, it is expected that the typology of the abnormality, associated with the species habitat, should be regarded as determinants for the post-natal survival period in abnormal individuals.

There are several causes referred as natural and anthropogenic agents implicated in the elasmobranch abnormalities, like parasite infection, mechanical injuries, physiological diseases, deficient nutrition, congenital abnormality and environmental conditions, but these assumptions may not always be conclusive in all cases (Rosa et al., 1996; Heupel et al., 1999; Mancini et al., 2006; Ribeiro-Prado et al., 2008; Escobar-Sánchez et al., 2009; Delpiani, et al., 2011; Wagner et al., 2013). Parasitic infestation seems to be excluded as a direct agent in prenatal elasmobranch anatomical anomalies.

Two major worldwide human threats imposed on elasmobranchs are the depletion of large portions of individuals from the wild population by the fisheries and the physical/chemical degradation of marine habitats (Dulvy et al., 2014).

The fishing pressures can reduce the genetic (nucleotides and haplotypes) diversity in an overexploited elasmobranch population due to loss of the reproductive stock, which implicates in bottleneck, expansion or selection process (Pereyra et al., 2010). Although not conclusively, the lower genetic variability for Rhizoprionodon lalandii along its geographical distribution (western Atlantic, from Caribbean to South Brazil (Figueiredo, 1977)) was detected at the São Paulo coast (Mendonça et al., 2013) a region under remarkable fishing pressure (Mendonça \& Miranda, 2008).

Concerning the environmental degradation, the elasmobranch high trophic level makes them exposed to accumulation of several contaminants (Gelsleichter \& Walker, 2010). The coast of São Paulo is under strong anthropogenic impact regarding the discharge of a large number of pollutants (Bicego et al., 2006; Araújo et al., 2013). Lacerda et al. (2000) showed that $R$. lalandii presented higher tissue concentration of mercury among the small coastal shark species, suggesting biomagnification according to the body growth. Anomalous embryos of $R$. lalandii here studied are from the same area where these genetic and ecotoxicological studies were performed.

Additionally, Motta et al. (2007) examined 137 embryos from 47 females between 1996 and 2002 from the same location where these anomalous embryos were recently sampled, and no abnormal individual was verified. Thus, the increase of recorded anatomical anomalies on elasmobranchs, seems to be not only a reflection of the academic interest in such research or the employment of advanced methodological tools to access embryological-genetic issues, but also because of the increase of litters having malformed embryos produced by genetic or physiologically affected parents. The direct influence of the high fishing mortality experienced by the elasmobranchs in recent times, and marine pollutants in its embryonic malformation was not conclusively presented to date, but can be assessed in the near future, through more detailed studies on abnormal embryos linked to the embryological, genetic and ecotoxicological approaches, aiming to establish public policies for the management of the several worldwide elasmobranch populations.

\section{ACKNDWLEDGEMENTS}

The authors thank Caroline C.T. Augusto, Catia Banjai and Priscila M. Dolphine for assistance with the radiographic procedures; Aline F. Pasquino and Mariana R.O.G. Gonçalves, for the general comments on the text; Ricardo O. Vasques, Renata Guedes, Silmara Loiola and the fishermen from Ilhéus (Bahia) and Praia Grande (São Paulo) for donating the embryos; and São Paulo's Research Support Foundation (FAPESP, \#2010/ 18448-0) and the Brazilian Council for Scientific Research (CNPq, \# 04600/2012) for their grants to C.M.H.S. and O.B.F.G., respectively.

\section{REFERENCES}

Anderson P.A., Huber D.R. and Berzins I.K. (2012) Correlations of capture, transport, and nutrition with spinal deformities in sandtiger sharks, Carcharias taurus, in public aquaria. Journal of Zoo and Wildlife Medicine 43, 750-758.

Andrade A.C., Silva-Júnior L.C. and Vianna M. (2008) Reproductive biology and population variables of the Brazilian sharpnose shark Rhizoprionodon lalandii (Müller \& Henle, 1839) captured in coastal waters of south-eastern Brazil. Journal of Fish Biology 72, 473-484.

Araújo G.S., Moreira L.B., Morais R.D., Davansso M.B., Garcia T.F., Cruz A.C.F. and Abessa D.M.S. (2013) Ecotoxicological assessment of sediments from an urban marine protected area (Xixová-Japuí State Park, SP, Brazil). Marine Pollution Bulletin 75, 62-68.

Ball R.E., Jones C.S., Lynghammar A., Noble L.R. and Griffiths A.M. (2013) The first confirmed cases of full albinism in rajid species. Journal of Fish Biology 82, 1433-1440.

Bejarano-Álvarez M., Galván-Maganã F. and Ocho-Baez R. (2011) Further observations on foetal abnormalities in the blue shark Prionace glauca (Chondrichthyes: Carcharhinidae) from north-west Mexico. Marine Biodiversity Records 4 e82, 1-3. doi: http://dx.doi. org/10.1017/S1755267211000790.

Ben Souissi J., Golani D., Merji H., Ben Salem M. and Capapé C. (2007) First confirmed record of the Halave's guitarfish, Rhinobatos halavi (Forsskål, 1775) (Chondrichthyes, Rhinobatidae) in the Mediterranean Sea with a description of albinism in elasmobranchs. Cahiers de Biologie Marine 48, 67-75.

Bícego M.C., Taniguchi S., Yogui G.T., Montone R.C., Silva D.A.M., Lourenço R.A., Martins C.C., Sasaki S.T., Pellizari V.H. and Weber R.R. (2006) Assessment of contamination by polychlorinated biphenyls and aliphatic and aromatic hydrocarbons in sediments of the Santos and São Vicente Estuary System, São Paulo, Brazil. Marine Pollution Bulletin 52, 1784-1832.

Bornatowski H. and Abilhoa V. (2008) Record of an anomalous embryo of Rhinobatos percellens in the southern coast of Brazil. Marine Biodiversity Records 2 e36, 1-3. doi:10.1017/S1755267209000414.

Castro-Aguirre J.L. and Torres-Villegas J.R. (1979) Sobre un caso de bicefalia functional en Rhinoptera steindachneri Evermann y Jenkins (Chondrichthys, Elasmobranchii Batoidei), capturado en la costa occidental de Baja California, Mexico. Ciencias Marinas 6, 27-41

Delpiani S.M., Antoni M.Y.D., Barbini S.A. and Figueroa D.E. (2011) First record of a dicephalic specimen of tope Galeorhinus galeus (Elasmobranchii: Triakidae). Journal of Fish Biology 78, 941-944.

Driggers W.B. III., Hannan K.M., Hoffmayer E.R. and Jensen J. (2012) Abnormal blacktip shark, Carcharhinus limbatus, embryo from the northern Gulf of Mexico. Journal of Applied Ichthyology 28, 827-828.

Dulvy N.K., Fowler S.L., Musick J.A., Cavanagh R.D., Kyne P.M., Harrison L.R., Carlson J.K., Davidson L.N.K., Fordham S.V., 
Francis M.P., Pollock C.M., Simpfendorfer C.A., Burgess G.H., Carpenter K.E., Compagno L.J.V., Ebert D.A., Gibson C., Heupel M.R., Livingstone S.R., Sanciangco J.C., Stevens J.D., Valenti S. and White W.T. (2014) Extinction risk and conservation of the world's sharks and rays. eLife. doi:10.7554/eLife.00590.

Ebert D.A., Fowler S. and Compagno L.J.V. (2013) Sharks of the world: a fully illustrated guide. Plymouth, UK: Wild Nature Press.

El Kamel O., Mnasri N., Boumaïza M. and Capapé C. (2009) Atypical abnormality in a common torpedo, Torpedo torpedo (Chondrichthyes: Torpedinidae) from the Lagoon of Bizerte (northern Tunisia, central Mediterranean). Cahiers de Biologie Marine 50, 97101.

Escobar-Sánchez O., Galván-Magaña F., Downton-Hoffman C.A., Carrera-Fernández M. and Alatorre-Ramírez V.G. (2009) First record of a morphological abnormality in the longtail stingray Dasyatis longa (Myliobatiformes: Dasyatidae) in the Gulf of California, Mexico. Marine Biodiversity Records 2 e26. doi: http://dx. doi.org/10.1017/S1755267208000304.

Evermann B.W. and Jenkins O.P. (1891) Report upon a collection of fishes made at Guaymas, Sonora, Mexico, with descriptions of new species. Proceedings of the United States National Museum 14, 121165.

Ferreira B.P. (1988) Ciclo reprodutivo de Rhizoprionodon lalandei (Valenciennes) e $R$. porosus (Poey) (Selachii, Carcharhinidae) na região de Barra de Guaratiba, RJ. Anais da Academia Brasileira de Ciências 60, 91-101.

Figueiredo J.L. (1977) Manual de peixes marinhos do sudeste do Brasil. São Paulo: Museu de Zoologia, Universidade de São Paulo.

Ford E. (1930) Some abnormal fishes received at the Plymouth Laboratory. Journal of the Marine Biological Association of the United Kingdom 17, 53-64.

Galván-Magaña F., Escobar-Sánchez $\mathbf{O}$. and Carrera-Fernández M. (2011) Embryonic bicephaly in the blue shark, Prionace glauca, from the Mexican Pacific Ocean. Marine Biodiversity Records 4 e1, 1-4. doi: http://dx.doi.org/10.1017/S1755267210001120.

Garrick J.A.F. (1982) Sharks of the genus Carcharhinus. NOAA Technical Report, National Marine Fisheries Service 445, 1-194.

Gelsleichter J. and Walker C.J. (2010) Pollutant exposure and effects in sharks and their relatives. In Carrier J.C., Musick J.A. and Heithaus M.R. (eds) Sharks and their relatives. II: biodiversity, adaptive physiology, and conservation. CRC Marine Biology Series. Boca Raton, FL: CRC Press, pp. $491-537$.

Gomes U.L., Santos H.R.S. and Medina A.E. (1991) Anophthalmia in Dasyatis sayi (LeSueur, 1817) (Myliobatiformes, Dasyatidae). Anais da Academia Brasileira de Ciências 63, 307-313.

Gopalan U.K. (1971) On two abnormal sharks from Gujarat. Journal of the Bombay Natural History Society 68, 465-466.

Goto M., Taniuchi T., Kuga N. and Iwata M. (1981) Four dicephalous specimens of the blue shark, Prionace glauca, from Japan. Japanese Journal of Ichthyology 28, 157-165.

Guida L., Walker T.L. and Reina R.D. (2013) First record of a bicephalic chondrichthyan found in Australian waters, the southern fiddler ray, Trigonorrhina dumerili (Chondrichthyes, Rhinobatidae). Marine and Freshwater Research. doi: 10.1071/MF13198.

Heupel M.R., Simpfendorfer C.A. and Bennett M.B. (1999) Skeletal deformities in elasmobranchs from Australian waters. Journal of Fish Biology 54, 1111-1115.

Hevia-Hormazábal V., Pastén-Marambio V. and Alonso V. (2011) Registro de un monstruo diprósopo de tiburon azul (Prionace glauca) en Chile. International Journal of Morphology 29, 509-513.
Hoenig J.M. and Walsh H.A. (1983) Skeletal lesions and deformities in large sharks. Journal of Wildlife Diseases 19, 27-33.

Joseph B. (1961) An albino cownose ray, Rhinoptera bonasus (Mitchill) from Chesapeake Bay. Copeia 4, 482-483.

Kamiya T., Miyazaki N. and Shiraga S. (1981) First case of dicephaly in odontoceti. Scientific Reports of the Whales Research Institute 33, $127-129$.

Kaufman M.H. (2004) The embryology of conjoined twins. Child's Nervous System 20, 508-525.

Kompanje E.J.O. (2005) A case of symmetrical conjoined twins in a bottlenose dolphin Tursiops truncatus (Mammalia, Cetacea). DEINSEA 11, 147-150.

Lacerda L.D., Paraquetti H.H.M., Marins R.V., Rezende C.E., Zalmon I.R., Gomes M.P. and Farias V. (2000) Mercury contents in shark species from the south-eastern Brazilian coast. Revista Brasileira de Biologia 60, 571-576.

Lessa R.P. (1988) Premières observations sur la biologie reproductive de Rhizoprionodon lalandei (Valenciennes, 1839) (Pisces, Carcharhinidae) de la côte nord du Brésil-Maranhão. Revista Brasileira de Biologia 48, 721-730.

Linnaeus C. (1758) Systema Naturae, Ed. X. (Systema naturae per regna tria naturae, secundum classes, ordines, genera, species, cum characteribus, differentiis, synonymis, locis. Tomus I. Editio decima, reformata.). Holmiae [Stockholm]: Laurentii Salvii.

Mancini P.L., Casas A.L. and Amorim A.F. (2006) Morphological abnormalities in a blue shark Prionace glauca (Chondrichthyes: Carcharhinidae) foetus from southern Brazil. Journal of Fish Biology $69,1881-1884$.

Mattos S.M.G., Broadhurst M.K., Hazin F.H.V. and Jonnes D.M. (2001) Reproductive biology of the Caribbean sharpnose shark, Rhizoprionodon porosus, from northern Brazil. Marine and Freshwater Research 52, 745-52.

Mejía-Falla P., Navia A.F. and Muñoz L.A. (2011) First record of morphological abnormality in embryos of Urotrygon rogersi (Jordan \& Starks, 1895) (Myliobatiformes: Urotrygonidae) in the Tropical Eastern Pacific. Latin American Journal of Aquatic Research 39, 184-188.

Mendonça J.T. and Miranda L.V. (2008) Estatística pesqueira do litoral sul de São Paulo: subsídios para gestão compartilhada. Pan-American Journal of Aquatic Sciences 3, 152-173.

Mendonça F.F., Oliveira C., Gadig O.B.F. and Foresti F. (2013) Diversity and genetic population structure of the Brazilian sharpnose shark Rhizoprionodon lalandii. Aquatic Conservation: Marine and Freshwater Ecosystems 23, 850-857.

Motta F.S., Gadig O.B.F., Braga F.M.S. and Namora R.C. (2005) Size and sex compositions, length-weight relationship, and occurrence of the Brazilian sharpnose shark, Rhizoprionodon lalandii, caught by artisanal fishery from southeastern Brazil. Fisheries Research 74, $116-126$.

Motta F.S., Namora R.C., Gadig O.B.F. and Braga F.M.S. (2007) Reproductive biology of the Brazilian sharpnose shark (Rhizoprionodon lalandii) from southeastern Brazil. ICES Journal of Marine Sciences 64, 1829-1835.

Müller J. and Henle F.G.J. (1839) Systematische Beschreibung der Plagiostomen. Berlin: Veit und Comp.

Muñoz-Osorio L.A., Mejía-Falla P.A. and Navia A.F. (2013) First record of a bicephalic embryo of smalltail shark Carcharhinus porosus. Journal of Fish Biology 82, 1753-1757. 
Nakaya K. (1973) An albino zebra shark Stegostoma fasciatum from the Indian Ocean, with comments on albinism in elasmobranchs. Japanese Journal of Ichthyology 20, 120-122.

Pastore M. and Prato E. (1989) A teratologic case in a shark. Thalassia Salentina 19, 87-92.

Pereyra S., Garcia G., Miller P., Oviedo S. and Domingo A. (2010) Low genetic diversity and population structure of the narrownose shark (Mustelus schmitti). Fisheries Research 106, 468-473.

Petrescu-Mag I.V., Păsărin B., Hoha G., Hărşan R. And Odagiu A.M. (2011) New contributions to knowledge of embryonic malformations in guppies. Aquaculture, Aquarium, Conservation \& LegislationInternational Journal of the Bioflux Society 4, 216-228.

Poey F. (1861) Memorias sobre la historia natural de la Isla de Cuba, acompañadas de sumarios Latinos y extractos en Francés. Tomo 2. Havana: Imprenta de Barcina.

Rafinesque C.S. (1810) Indice d'ittiologia siciliana; ossia, catalogo metodico dei nomi latini, italiani, e siciliani dei pesci, che si rinvengono in Sicilia disposti secondo un metodo naturale e seguito da un appendice che contiene la descrizione de alcuni nuovi pesci siciliani. Messina: G. del Nobolo.

Ribeiro-Prado C.C., Oddone M.C., Gonzalez M.M.B., Amorim A.F. and Capapé C. (2008) Morphological abnormalities in skates and rays (Chondrichthyes) from off southeastern Brazil. Arquivos de Ciências do Mar 41, 21-28.

Rosa R.S., Gomes U.L. and Gadig O.B.F. (1996) Um caso de teratogenia na raia e água doce Potamotrygon motoro (Natterer in Müller e Henle, 1841) (Chondrichthyes: Potamotrygonidae). Revista Nordestina de Biologia 11, 125-132.

Rüppell W.P.E.S. (1837) Neue Wirbelthiere $z u$ der Fauna von Abyssinien gehörig. Fische des Rothen Meeres. Frankfurt am Main: Siegmund Schmerber.
Spencer R. (2000) Theoretical and analytical embryology of conjoined twins: Part I: embryogenesis. Clinical Anatomy 13, 36-53.

Springer V.G. (1964) A revision of the carcharhinid shark genera Scoliodon, Loxodon, and Rhizoprionodon. Proceedings of the United States National Museum 115, 559-632.

Tate E.E., Anderson P.A., Huber D.R. and Berzins I.K. (2013) Correlations of swimming patterns with spinal deformities in the sand tiger shark, Carcharias taurus. International Journal for Comparative Psychology 26, 75-82.

Teixeira S.F. and Araújo M.L.G. (2002) First record of albinism in the smooth dogfish Mustelus schmitti Springer, 1939 (Carcharhiniformes, Triakidae) from southern Brazil. Brazilian Archives of Biology and Technology 45, 241-243.

Wagner C.M., Rice P.H. and Pease A.P. (2013) First record of dicephalia in a bull shark Carcharhinus leucas (Chondrichthyes, Carcharhinidae) foetus from the Gulf of Mexico, U.S.A. Journal of Fish Biology 82, $1419-1422$.

and

Whitley G.P. (1929) Additions to the check-list of the fishes of New South Wales. No. 2. Australian Zoologist 5, 353-357.

\section{Correspondence should be addressed to:}

\section{C.M.H. Santos}

Laboratório de Pesquisa de Elasmobrânquios UNESP, Campus Experimental do Litoral Paulista Praça Infante Dom Henrique s/n, 11330-900 São Vicente, São Paulo, Brasil email: camilamhs@hotmail.com 